\title{
Effects of Adding Natural Blends of Kaolin and Spices on Broiler Performance, Meat and Bone Quality
}

\author{
L. Sahraoui, D. Ouachem, S. Lombarkia
}

10.18805/ag.DF-378

\begin{abstract}
Background: The aim is to compare the effectiveness of $3 \%$ of natural preparations mixtures based on kaolin associated with garlic, ginger and/or their mixture on the performance, the cutting yield, carcass and bone qualities of broiler.

Methods: 192 one-day-old Cobb 500 chicks were assigned to 04 groups of 48 four-replicate chicks (C: without addition; Kgar: $3 \%$ kaolin-garlic; Kgin: 3\% kaolin-ginger and Kgg: 3\% kaolin-garlic-ginger).

Result: Results showed that the mixtures significantly improve body weight and feed efficiency at 42 days, with nonetheless a more marked effect for the Kgar group (BW: $+4.5 \%$; FCR: $-5.5 \%$ ). In addition, still in favor of the Kgar group, the same tendency was recorded for the yield of chicken ready-to-cook $(+3.2 \%$; $P=0.02)$ accompanied by enhanced breast and thighs yields. In terms of quality, the mixtures significantly impacted the meat conservation criteria by reducing water-holding capacity by almost $50 \%$ and less abdominal fat deposition. Finally, although not significant, the indicators of bone quality measured (ash content and Seedor index) appear better in chickens receiving mixtures. The results of this study show the interest of adding a mixture of kaolin and condiments in improving broiler performance, meat quality and bone characteristics.
\end{abstract}

Key words: Bone, Clay, Condiments, Feed conversion ratio, Quality, Weight gain.

\section{INTRODUCTION}

Growth promoters have improved in the optimization of poultry performance. Unfortunately, scientists, governments and consumers have strongly opposed their usage due to concerns about anti-biological resistance and the accumulation of residues in animal products. So, various natural substances such as phytobiotics, spices, extracts, enzymes, clays and others were recommended as feed additives that improve intestinal health, feed efficiency, welfare, performance and environmental conservators (Ouachem et al. 2015a, Byoung et al. 2020). Bibliographically available results have generally been observed in studies using these additives alone and very little in mixtures. For this purpose, it is proposed to study the response of chicken to the addition of a natural preparation based on kaolin mixed with garlic, ginger and/ or ginger- garlic mixtures. Garlic and ginger are among the phyto additives commonly used in phytotherapy and poultry feeding. These condiments are characterized by their richness in bioactive components which confer antioxidant, antimicrobial and anti-inflammatory activities (Prasad et al. 2009, Hanieh et al. 2010, Mahboubi, 2019). Moreover, kaolin is abundant clay in nature, cheap, recommended in poultry feed for its opportunistic effects on weight gain, feed efficiency and its antimicrobial and detoxifying effect on the digestive tract (Ouachem et al. 2015a).

\section{MATERIALS AND METHODS Diets, clay and condiments}

Starter and growth basal diets were formulated without preservatives and coccidiostats according to the nutritional
Laboratory of Food Sciences, Institute of Veterinary and Agronomic Sciences, Batna1 University, 05000 Algeria.

Corresponding Author: D. Ouachem, Laboratory of Food Sciences, Institute of Veterinary and Agronomic Sciences, Batna1 University, 05000 Algeria. Email: oduniv@yahoo.fr

How to cite this article: Sahraoui, L., Ouachem, D. and Lombarkia, S. (2021). Effects of Adding Natural Blends of Kaolin and Spices on Broiler Performance, Meat and Bone Quality. Agricultural Science Digest. DOI: $10.18805 /$ ag.DF-378.

Submitted: 14-07-2021 Accepted: 04-12-2021 Online: 25-12-2021

recommendations of the Cobb 500 strain guide published in 2018. Foods consist mainly of corn and soybeans, the chemical composition and nutritional characteristics of the starter (J1-J14) and growth (J15-J42) diets are respectively: (3000 Kcal ME/kg; $21 \%$ crude protein; $0.87 \% \mathrm{Ca} ; 0.43 \%$ total $\mathrm{P}$ and $1.17 \%$ lysine); (3150 Kcal ME / kg; $19 \%$ crude protein; $0.76 \% \mathrm{Ca} ; 0.38 \%$ total $\mathrm{P}$ and $1.02 \%$ digestible lysine). Garlic and ginger were mixed with kaolin and incorporated in experimental diets. The kaolin is characterized by a particle size containing $64 \%$ kaolinite, $25 \%$ micaceous materials and other clays, $8 \%$ quartz and $3 \%$ feldspar. Its chemical composition is shown in Table 1.

\section{Experimental design}

This study was carried out from May 5 to June 15, 2019 at the experimental station of the Institute of Veterinary and Agronomic Sciences of Batna 1 University (Algeria) on a total of 192, 1-d-old Cobb 500 broiler chicks, randomly distributed through four treatments. Per treatment, 48 chicks were placed in four cages (04 repetitions per pen). Chicks 
of different treatments were feed the following diets: (C: without addition; Kgar: addition of $3 \%$ of kaolin-garlic mixture; Kgin: addition of $3 \%$ of kaolin-ginger mixture and $\mathrm{Kgg}$ : addition of $3 \%$ kaolin-garlic-ginger mixture). At 42 days, the body weight and the feed efficiency were recorded. Then, two broilers per lot (08 / treatment) were weighed individually, slaughtered (according to religious ritual by deep and rapid incision of the neck with a knife, so as to cut the jugular vein and the carotid artery bilaterally and quickly, but leaving the spinal cord, so that the convulsions drain the blood from the body of the chicken), plucked and eviscerated. The carcasses were weighed and cut to assess the yield of readyto-cook chicken, the yields of breast, thigh and drumstick. To determine the drip loss, the right breasts were weighed, packed in freezer bags and suspended by a hook for 4 days at $2^{\circ} \mathrm{C}$. At the end of the chilling, the muscle was wiped with absorbent paper and reweighed to evaluate the water loss (Ouachem et al. 2011).

To appreciate the bone quality, the right tibias of slaughtered broilers have been stripped of soft tissue, weighed and their lengths measured using an electronic caliper, degreased with ether $(24 \mathrm{~h})$, dried $\left(105^{\circ} \mathrm{C} / 12 \mathrm{~h}\right)$, then weighed before being incinerated in a muffle furnace $\left(550^{\circ} \mathrm{C}\right.$ $114 \mathrm{~h}$ ) and after cooling, the ashes were weighed (Jondreville et al. 2007). The bone density or tibia index is the assessment indicators of bone strength. Bone density was determined by:

$$
\text { Seedor Index }=\frac{\text { Tibia weight }(\mathrm{mg})}{\text { Tibia length }(\mathrm{mm})}
$$

(Seedor et al. 1991)

\section{Statistical analysis}

The means of the various parameters studied were compared by a one-way analysis of variance (Anova) test, followed by pairwise comparisons between groups using Tukey's test. Differences at $\mathrm{P}<0.05$ were considered significant. Statistical analysis was performed with SPSS version 23.0 for windows software.

\section{RESULTS AND DISCUSSION \\ Growth performances}

The results of Table 2 show that adding mixtures significantly improved body weight $(P=0.02)$ and feed efficiency $(P<0.05)$. Compared to the control, this effect is more pronounced for the Kgar group (BW: $+4.5 \%$, FCR: $-5.5 \%$ ). Overall, this is consistent with the results of some available references on the use of mixtures of clays and phytobiotics. This consistency corroborates the responses observed in broiler by Tzora et al. (2017) with a mixture of natural substances based on clay (attapulgite), oregano and benzoic acid extracted from mulberry. According to these authors, addition of $4.5 \mathrm{~g} / \mathrm{kg}$ of feed, significantly increases the slaughter weight $(+8 \%)$ and improves FCR $(-11.7 \%)$. This was attributed to the positive effect of polyphenols on the jejunal enterobacteria proliferation. Otherwise, Skoufos et al. (2016) report that the addition of a mixture composed of attapulgite and oregano powder, improves significantly the body weight and FCR $(+8.2 \%,-6 \%)$ with fall in mortalities $(-16.8 \%)$. This finding was explained by the buffering effect of clay (attapulgite) and the antimicrobial activity of oregano leading to a notable decrease of the total ileo caecal coliforms and lactobacilli proliferation. Furthermore, in Aigamo duck, the use of increasing doses of mixtures based on clays (zeolite and vermiculite) and extracts of tropical fruits (pineapple and papaya), stimulates body weight $(+3 \%)$ and stabilizes the feed efficiency in a variable range of 3 to $4.4 \%$ (Khambualai et al. 2009). The results previously published by Simon et al. (2011) support the findings of the present study and also show that the use of $0.5 \%$ of natural extract and clay materials optimizes the 7 days weight $(+4 \%)$ and consequently promotes a best start, while greatly reducing mortality $(-15 \%)$. Similarly, in laying hens, Ouachem and Lombarkia (2017) reported that the addition of $3 \%$ of natural preparation based on kaolin and phytobiotics (mild paprika, turmeric and olive leaves) improves the FCR (-2.4\%) and egg mass (+3.1\%). These improvements are attributed to the physicochemical and biological properties of the bioactive molecules that make up the mixtures.

\section{Carcass and cutting yields}

Compared to the control, the addition of mixtures promotes a significantly better yield of ready-to-cook chicken in favor of Kgar group (+3.2\%). Moreover, although not significant, the mixtures still stimulate the breast yield. This response doesn't differ from the results reported by Saçakli et al. (2015) who reported an increase in breast yield (+10\%) and thigh $(+4 \%)$ with $2 \%$ of a natural zeolite and yeasts mixture. However, under experimental conditions using $3 \%$ of garlic and ginger mixture, it was recorded by Olagoke et al. (2019) a significant improvement in the relative weight of the thigh $(+13.5 \%)$ and drumstick (+4.6\%). Likewise, improvements of carcass and cutting yield observed in the present study can be attributed to the clay introduced as reported by Ouachem et al. (2015b) with $3 \%$ of marl or kaolin. Such effects have been explained by the activity of phenolic compounds and certain ketone derivatives present in spices on the increase of serum proteins and globulins (Ogbuewu and Mbajiorgu, 2020).

\section{Carcass and bone quality indicators}

The observed decrease in abdominal fat was also found in chicken $(-10 \%)$ with a mixture of sepiolite and natural beet extract (Uzunoðlu and Yalçin, 2019). Recently, Rastad (2020) recorded a significant decrease in abdominal fat with a mixture of probiotic and garlic powder $(-41 \%)$ and on the other hand, the addition of garlic and ginger promotes higher protein utilization and improves the storability of meat (Adomeh and Eguaoje, 2019). With a 3\% blend (50/50) of garlic and ginger, Olagoke et al. (2019) obtained significantly reduced fat in chickens (-57\%). Moreover, the use of marl in the chicken diet has been accompanied by positive effects on the meat quality, in particular, its water holding capacity, its storage ability and a decrease in abdominal fat (Ouachem 
Effects of Adding Natural Blends of Kaolin and Spices on Broiler Performance, Meat and Bone Quality

Table 1: Chemical composition of kaolin (in per cent).

\begin{tabular}{cccccccccc}
\hline $\mathrm{SiO}_{2}$ & $\mathrm{Al}_{2} \mathrm{O}_{3}$ & $\mathrm{Fe}_{2} \mathrm{O}_{3}$ & $\mathrm{TiO}_{2}$ & $\mathrm{CaO}$ & $\mathrm{MgO}$ & $\mathrm{K}_{2} \mathrm{O}$ & $\mathrm{Na}_{2} \mathrm{O}$ & $\mathrm{OM}^{(1)}$ & $\mathrm{CEC}^{(2)}$ \\
\hline 49.30 & 33.00 & 2.50 & 0.24 & 0.08 & 0.40 & 2.90 & 0.1 & 0.48 & 14 \\
\hline
\end{tabular}

(1): organic matter; (2): cation exchange capacity in milliequivalents per $100 \mathrm{~g}$ of soil.

Table 2: Effects of the addition of $3 \%$ of mixtures of natural substances based on kaolin associated with garlic, ginger and / or their combination in chickens.

\begin{tabular}{|c|c|c|c|c|c|c|}
\hline Variables & C & Kgar & Kgin & Kgg & SEM & Value of $P$ \\
\hline \multicolumn{7}{|c|}{ Growth performances } \\
\hline Feed conversion ratio & $1,82^{\mathrm{a}}$ & $1,72^{\mathrm{b}}$ & $1,79^{\mathrm{ab}}$ & $1,77^{\mathrm{ab}}$ & 0.014 & $P<0.05$ \\
\hline \multirow[t]{2}{*}{ Body weight (g) } & $2372^{\mathrm{b}}$ & $2479^{a}$ & $2430^{\mathrm{ab}}$ & $2417^{a b}$ & 12.64 & $P=0.02$ \\
\hline & & & \multicolumn{2}{|c|}{ Carcass and cutting yields (\%) } & & \\
\hline BRC & $70 \mathrm{~b}$ & $72,25^{\mathrm{a}}$ & $71,12^{\mathrm{ab}}$ & $71,25^{\mathrm{ab}}$ & 0.27 & $P=0.02$ \\
\hline Breast & 20,5 & 22,26 & 22,45 & 21,76 & 0.17 & No significant \\
\hline Thigh & 11,97 & 12,75 & 12,03 & 12,16 & 0.08 & No significant \\
\hline \multirow[t]{2}{*}{ Drumstick } & 10,59 & 11,03 & 10,69 & 10,72 & 0.06 & No significant \\
\hline & \multicolumn{5}{|c|}{ Carcass and bone quality indicators } & \\
\hline Abdominal fat (\% BW) & 1,05 & 0,88 & 0,86 & 0,95 & 0.029 & No significant \\
\hline Drip loss* & $5,69^{a}$ & $2,9^{b}$ & $3,56^{b}$ & $2,85^{b}$ & 0.28 & $P<0.001$ \\
\hline Bone Ash \% & 47,83 & 49,61 & 49,48 & 49,07 & 0.28 & No significant \\
\hline Index of Seedor (IS) & 72,7 & 75,9 & 73,46 & 72,09 & 1.43 & No significant \\
\hline
\end{tabular}

a, bDifferent superscripts in a line indicate significant differences between the groups, $p<0.05$; $(B R C)$ : Yield of broiler ready-to-cook;

$\left({ }^{*}\right)$ : in $\%$ of breast weight.

et al. 2011). According to Reis et al. (2018), addition of thymol, carvacrol and cinnamic aldehyde also decreases the drip loss and improves the ability of meat preservation. These effects were explained by the enhanced digestive efficiency of proteins and lipids motivated by the potential effect of clays on gut health and nutrient absorption (Ouachem et al. 2015a). Nevertheless, referring to bibliographic data, it should be noted the lack of work on the effect of mixtures of clay and condiments on bone quality. Nonetheless, Travel et al. (2014) reported that the use of natural compost based on kaolin, sand and earthworms increases the egg-shell weight, while in broilers (Safaei Katouli et al. 2012), the addition of kaolin, bentonite or zeolite promotes better bone density. Also, Ouachem et al. (2017) showed that the addition of $3 \%$ marl or kaolin significantly increases the tibia index and its relative weight. These positive responses can be attributed to clays high cation exchange capacity as well as their richness of mineral content. It should be remembered that it has been shown that an excess of phosphorus tends to deteriorate the egg shell quality (Elliot and Edward, 1991), while clays interfere with the absorption of phosphorus (Zimmermann, 2014), in particular, the ability of the aluminum contained in clays to form a complex with excess phosphorus (Ma and Ryan, 2010), thereby improving the eggshell quality. In addition, these effects can be explained by the richness of clays in Al, Si, Zn, $\mathrm{Na}$ or $\mathrm{K}$. These minerals are known to influence mineral metabolism and electrolytic balance, leading to bone development and maturity. This effect on bone is interesting because in fast growing broilers skeletal disorders are common so that bone development fails to keep pace with growth and excess muscle mass and predisposes the bone to deformation and bone fragility, leading to degradation of bedding, a drop in performance and considerable carcass defects.

\section{CONCLUSION}

The results of this trial suggest that the addition of $3 \%$ of natural preparations mixtures based on kaolin associated with condiments mixture provides positive effects to growth performance, cutting yield, carcass and bone qualities. The kaolin-garlic mixture, in particular, encourages poultry operators to reposition themselves for a possible ambitious application of the mixture investigated in poultry feed as a natural supply growth promoter and poultry welfare. Further other studies in intensive industrial breeding, in less favorable breeding conditions or even in vitro are however recommended to validate these results.

\section{REFERENCES}

Adomeh, E.E. and Eguaoje, A.S. (2019). Performance and organoleptic qualities of broiler chickens fed and raised with varying levels of ginger and garlic mixture. Nigerian Journal of Animal Science. 21(2): 310-318.

Byoung, B.S., Sam, C.K., Young, H.J., Hyuk, J.L., Tae, H.C. and In-Hag, C. (2020). Egg production in laying hens receiving different forms of red ginseng and fermented red koji blend. Indian Journal of Animal Research. 54(10): 1304-1308.

Cobb 500. Poulet de chair : performances et recommandations nutritionnelles. Edition 2018 https://www.cobb-vantress. com/assets/Cobb-Files/a54d5b4201/Cobb500-Broiler Performance-and-Nutrition-Supplement-French-v2.pdf. consulted on $05 / 24 / 2021$. 
Effects of Adding Natural Blends of Kaolin and Spices on Broiler Performance, Meat and Bone Quality

Elliot, M.A. and Edwards, H.M. Jr. (1991). Comparison on the effects of synthetic and natural zeolite on laying hen and broiler chicken performance. Poultry Science. 70: 2115-2130.

Hanieh, H., Narabara, K., Piao, M., Gerile, C., Abe, A. and Kondo, Y. (2010). Modulatory effects of two levels of dietary Alliums on immune responses. Animal Science Journal. 81: 673-680.

Jondreville, C., Genthon, C., Bouguennec, A. and Nys, Y. (2007). Use of Triticale in Broiler Feed: Estimation of the Effectiveness of Plant Phytase in Improving Phosphorus Availability. $7^{\text {th }}$ Poultry Research Days, Tours (France), March 2829: 253-257.

Khambualai, O., Ruttanavut, J., Kitabatake, M., Goto, H., Erikawa, T. and Yamauchi, K. (2009). Effects of dietary natural zeolite including plant extract on growth performance and intestinal histology in Aigamo ducks. British Poultry Science. 50(1): 123-130.

Ma, J.F. and Ryan, P.R. (2010). Foreword: Understanding how plants cope with acid soils. Functional Plant Biology. 37(4): iii-vi.

Mahboubi, M. (2019). Zingiber officinale Rosc. essential oil, a review on its composition and bioactivity. Clinical Phytoscience. 5(1): $1-12$.

Olagoke, O.C., Akinwumi, A.O. and Emiola, I.A. (2019). Growth performance and carcass characteristics of broiler chicken fed diet supplemented with ginger (Zingiber officinale), garlic (Allium sativum), roselle (Hibiscus sabdariffa) and their cmbinations. International Journal of Research in Agricultural Sciences. 6(5): 2348-3997.

Ogbuewu, I.P. and Mbajiorgu, C.A. (2020). Supplementation and optimization of ginger (Zingiber officinale) rhizome powder in growing rabbit diets. Indian Journal of Animal Research. 54(9):1120-1124.

Ouachem, D., Bakroune, F., Bensalem, A., Hadjar, A. and Abdessemed, F. (2011). Effects of Marl on Cutting Yield and Meat Quality of Broiler Chicken. 9 ${ }^{\text {th }}$ Poultry Research Days, Tours (France), March 29-30: 667-671.

Ouachem, D., Kaboul, N., Meredef, A., Abdessemed, F. and Ahmed Gaid, Z. (2015a). Effects of clay on performance, moisture of droppings and health status of poultry: An overview. World's Poultry Science Journal. 71(1): 184-189.

Ouachem, D., Kaboul, N. and Meredef, A. (2015b). The Marl and Kaolin in Broiler Diet: Effects on the Bone Weight and the Cutting Yield. $6^{\text {th }}$ International Seminar on Tropical Animal Production, October 20-22, Yogyakarta, Indonesia.

Ouachem, D. and Lombarkia, S. (2017). Effects of a Natural Preparation Based On Kaolin, Olive Leaf, Turmeric and Mild Paprika on the Performance of Laying Hens. $7^{\text {th }}$ International Seminar on Tropical Animal Production, September 12-14, Yogyakarta, Indonesia.

Ouachem, D., Meredef, A., Arfan, Z. and Bennoune, O. (2017). Improvement of the intestinal mucosa, the droppings, bones and growth of broiler chickens by marl. Livestock Research for Rural Development. 29(6). http://www.Irrd.org /.../odun29121.html.
Prasad, R., Rose, M.K., Virmani, M., Garg, S.L., Puri, J.P. (2009). Effect of garlic (Allium sativum) supplementation on hematological parameters in chicken (Gallus domesticus). Indian Journal of Animal Research. 43(3): 157-162.

Rastad, A. (2020). Effects of antibiotic replacement with garlic powder and probiotic on performance, carcass characteristics, oxidative enzymes and intestinal morphology of broiler chickens. Acta Scientiarum. Animal Sciences. 42(1): elocation e48734.

Reis, J. H., Gebert, R.R., Barreta, M., Baldissera, M.D., Dos Santos, I.D., Wagner, R. and Mendes, R.E. (2018). Effects of phytogenic feed additive based on thymol, carvacrol and cinnamic aldehyde on body weight, blood parameters and environmental bacteria in broilers chickens. Microbial Pathogenesis. 125: 168-176.

Safaei Katouli, M., Boldaji, F., Dastar, B. and Hassani, S. (2012). Growth response and tibia bone characteristics in broilers fed diets containing kaolin, bentonite and zeolite. Journal of Animal and Feed Science. 21(2): 334-344.

Saçakli, P., Calik, A., Bayraktaroğlu, A.G., Ergün, A., Şahan, Ö. and Özaydin, S. (2015). Effect of clinoptilolite and/or phytase on broiler growth performance, carcass characteristics, intestinal histomorphology and tibia calcium and phosphorus levels. Kafkas Universitesi Veteriner Fakültesi Dergisi. 21(5): 729-737.

Seedor, J. G., Quartuccio, H. A. and Thompson, D.D. (1991). The bisphosphonate alendronate (MK-217) inhibits bone loss due to ovariectomy in rats. Journal of Bone and Mineral Research. 6(4): 339-346.

Simon, E., Domitile, R. and Desbordes, P. (2011). Effect of the Use of Plant Extracts and Alumina Silicates in Conventional Broiler Farming on the Litter Quality, the Prevalence of Pododermatitis and Zootechnical Performance. 9 $9^{\text {th }}$ Poultry Research Days, Tours (France), pp: 226-230.

Skoufos, I., Giannenas, I., Tontis, D., Bartzanas, T., Kittas, C., Panagakis, P. and Tzora, I. (2016). Effects of oregano essential oil and attapulgite on growth performance, intestinal microbiota and morphometry in broilers. South African Journal of Animal Science. 46(1): 77-88.

SPSS (2019). Statistical package for social Sciences. Version 23 Procedure and Facilities for Research Mc-Graw Hill Book Co. New York.

Travel, A., Le François, M., Hallouis, J.M., Jurjanz, M., Lessire, M., Yves, N. and Jondreville, C. (2014). Effect of the nature and amount of soil ingested on the energy recovery of food and egg production. The veterinary week $N^{\circ} 1585$.

Tzora, A., Giannenas, I., Karamoutsios, A. and Papaioannou, N. (2017). Effects of oregano, attapulgite, benzoic acid and their blend on chicken performance, intestinal microbiology and intestinal morphology. Journal of Poultry Science. 54: 218-227.

Uzunoğlu, K. and Yalçin, S. (2019). Effects of dietary supplementation of betaine and sepiolite on performance and intestinal health in broilers. Ankara Üniversitesi Veteriner Fakültesi Dergisi. 66: 221-229.

Zimmermann, O.F. (2014). A Natural Zeolite in Growth and Finishing Feed of Pigs. Master thesis in Animal Sciences, Santa Catarina University, 86p. 